\title{
MULTILINGUALISM AND LANGUAGE CONTACT IN WEST AFRICA: TOWARDS A HOLISTIC PERSPECTIVE
}

\author{
Friederike Lüpke
}

\author{
School of Oriental and African Studies, University of London
}

Endangered Languages Academic Programme,

\author{
"[t]he study of contact-induced change of \\ whatever kind is no longer of secondary \\ importance. It has moved from side to center \\ stage." \\ Robert Nicolaï. Language Contact : a \\ Blind Spot in 'Things Linguistic', \\ Journal of Language Contact, Thema1, \\ 2007:11.
}

\section{West Africa as a contact area}

Contemporary West Africa is characterized by extensive societal multilingualism going hand in hand with cultural hybridity. This situation type is characterized by a complex interaction between two or more languages in an individual's brain as well as in an entire society. The historical causes of the multilingual profile of this region lie in the succession of empires emerging in the area from $300 \mathrm{BCE}$ onward and culminating in the Mali empire around 1250-1450 CE (Davidson 1998; Levtzion 1973). The social, economic and religious impact of these empires on the societies in their realm was and is enormous: throughout the regions concerned, cross-cutting ethnic and linguistic borders, we find similar systems of social organization, as evidenced by identical caste systems (Tamari 1991, 1997), secret societies, and landlord-stranger relationships (Brooks 1980, 1993). Major trade routes traverse the area, also serving the spread of Islam as the dominant religion (Ajayi and Crowder 1985, Brooks 1980). Arabic and Jula as the languages of Islam and trade, and later French, English and Portuguese as the colonial languages have also left imprints on most of the languages and cultures in question. Urbanization due to massive rural exodus is the most recent factor motivating multilingualism and language contact, but is at the same time dramatically changing its dynamics (McLaughlin 2001; Vigouroux and Mufwene 2009). The resulting multilingualism makes notions like 'mother tongue' and 'first' and 'second language' problematic in many ways and is reflected in vague, multiple and easily changeable ethnic affiliations (Amselle 1990, 1996; Amselle and Royal 1998; Amselle and M'Bokolo 1999; Brooks 1993; Bruijn and Dijk 1997). The (ex-colonial) official languages play only a minor 
role in the most common multilingual repertoires, contrarily to their visibility, status and representation in research.

\section{The importance of language contact for linguistic structure}

Multilingualism of the kind encountered in West Africa entails intense language contact, mainly between African languages. Contact between languages is an important contributor to language change through the transfer of linguistic material (forms, meanings, and formmeaning associations) from one language to the other (Heine and Kuteva 2005; Matras 2009; Myers-Scotton 2002; Romaine 1989; Thomason and Kaufman 1988; Thomason 2001; Weinreich 1953). The intense type of contact present in the area is generally predicted to result in pervasive lexical and structural borrowings that affect all areas of language, but the extent and limits of structural interferences, in particular, are contentious (see e.g. Thomason (2001) pace Mous (2003) on the borrowability of noun classes). However, multilingualism and in language contact between African languages is dramatically underresearched. Therefore, despite a general awareness of the area as one of great linguistic and cultural convergence and the existence of a number of important studies on sociolinguistic profiles (Dreyfus and Juillard 2007; Juillard 1995), language attitudes (e.g. Canut 1996; Dumestre 1994) and code-switching (e.g. Haust 1995), little is known about the linguistic consequences of specific contact scenarios, and even less about contrasting scenarios involving the same languages. The scarce existing studies on contact phenomena between individual languages (e.g. Beyer 2006, 2009; Dombrowsky-Hahn 1999; Drolc 2005; Nicolaï 2005; Turay 1978) point to considerable structural parallelisms permeating all areas of grammar, as is to be expected in situations of intense and extended contact, but also suggest that the direction of contact-induced influence can be the opposite of sociolinguistic factors attested elsewhere or exhibit no clear directionality or straightforward correlation with social factors altogether. Deplorably, however, these data on linguistic interferences often cannot be meaningfully interpreted, since, in general, studies on multilingualism are not directly associated with the description and documentation of the languages in question. In the absence of detailed descriptions and documentary corpora of the languages in contact, coupled with detailed sociolinguistic information, it is almost impossible to establish whether convergences between them are due to universal constraints on linguistic structure, to a shared genealogy, to parallel yet independent innovations, to chance, or to contact-induced interferences. Despite the fact that West African languages are almost exclusively spoken in multilingual speech communities, descriptive and documentary efforts generally focus on one language, regardless of the linguistic profile of the speech community, and do not systematically include variations in language use, whether the latter involve the choice of language(s), dialects, styles or registers.

\section{The importance of language contact for language change}

The dominant research focus within African descriptive linguistics has been on languageinternal factors for change, and genetic relationships between languages (but see Heine and Kuteva 2005 for a notable exception). To date, our understanding of the internal relationships within the major subgroups of Niger-Congo, as in the case of the Atlantic languages, and their position within the phylum, as in the case of Mande, is limited. The exact genetic affiliations of Dogon and Songhay, for instance, remain a matter of dispute, (Dimmendaal 2008; Nicolaï 2005). To give only one example, for Mande languages, recent classifications based on shared lexical innovations (Kastenholz 1996) and phonological characteristics (Schreiber 2008) come to partly conflicting conclusions, but there are huge gaps in the data due to the lack or paucity of descriptions. The position of Mande as a whole within Niger-Congo is odd, given the absence of 'prototypical' Niger-Congo features such as noun classes (but see Vydrin (1989) for an analysis that comes up with traces of noun classes in Mande languages). Regarding Atlantic languages, only one detailed comparative study exists to date (Sapir 1971), and newer studies (Podzniakov 2007; Wilson 1989) go so far as to question the 
validity of Atlantic as anything more than a geographical or at best as a typological grouping altogether. Again, it is not only a lack of linguistic descriptions and/or of comparable data that hinders progress in this domain, but also the absence of data on variation, change, and their causes. These data are indispensable in order to understand how language-internal factors (for instance, sound change or reanalysis) and language-external factors (for instance, language attitudes or contact-induced interferences) interact to shape the structure and lexicon of the languages concerned, and how these factors could be modelled. Recent publications stress the importance of linguistic areas (Heine and Nurse 2008; Matras et al. 2006), but the areas proposed for Africa suffer from a lack of descriptive information, as in the case of Güldemann's suggested 'macro-Sudan belt' (Güldemann 2008). While Williamson and Blench (2000) believe in a possible reconstruction of the internal structure of Niger-Congo, rendered difficult mainly by "the large number of languages, the inaccessibility of much of the data, and the paucity of able researchers committed to this field" (2000:12), an integrated approach exploring how genealogy and contact together have shaped the languages of this area seems much more promising in yielding models of language change informed by the social and historical realities of the speakers of the languages in question.

\section{The state of the art of West African contact linguistics}

Against this backdrop, the contributions gathered in this volume present the state of the art for a number of languages and multilingual and contact situations in West Africa, illustrating the nature of the data available and the methodological and interpretive challenges they pose, and suggesting new directions of research to be taken in the future. The articles stem from two exploratory workshops aiming at charting the territory for an inter- and multi-disciplinary investigation of West African multilingualism and language contact. The first workshop looked specifically at language contact between languages of the West African Mande and Atlantic groups of Niger-Congo; the second investigated possibilities for developing inter-and multi-disciplinary research agendas on language contact in West Africa more generally. ${ }^{1}$ While both workshops brought together researchers working on African languages spoken and written in the area from different and disciplinary backgrounds, the following two observations on their profiles exemplify the new central role of language contact. Firstly, none of the participants was a 'contact linguist' in the narrow sense, i.e. a researcher investigating explicitly and exclusively the social factors for patterns of multilingualism or the structural outcomes of speaking several languages in an individual or an entire society. Secondly, the contributions reflect disciplinary boundaries very strongly - most linguists, for example, tend to prioritise the structural outcomes of language contact, seeking extralinguistic information when needed to back up their hypothetical contact scenarios, whereas sociolinguists focus on attitudes and linguistic repertoires, but do not investigate their linguistic consequences. However, all of the participants and contributors to this issue felt that understanding and describing contexts, patterns and consequences of multilingual language use was essential for their own work.

In my opinion, these observations do not derive from a biased selection of participants; rather, I would like to argue, they are systematic and point to central facts to be taken into account in order to assess the state of multilingualism and contact studies in West Africa:

\footnotetext{
${ }^{1}$ The first workshop, funded by the European Science Foundation (ESF), was an Exploratory Workshop with the title "Documenting convergence and diversity: Mande and Atlantic languages in contact. It was convened by Friederike Lüpke and held at SOAS, London, in 2008. The second workshop, "Multidisciplinary perspectives on language contact in West Africa", was a Project Development Workshop organised by Klaus Beyer and Friederike Lüpke, sponsored by the Deutsche Forschungsgemeinschaft (DFG), and took place at the Académie Point Sud in Bamako, Mali. The support of ESF, DFG and Point Sud is gratefully acknowledged.
} 
1. There are very few, if any, studies that describe not the contact between an official/European languages with a well established and enforced discrete identity and one or several African languages (e.g. Creole studies, Myers-Scotton 1993; Swigart 1994; McLaughlin 2001, 2008, etc.), but contact between and multilingualism in African languages. The reasons for this limitation lie in the unsatisfactory amount of sociolinguistic, descriptive and documentary knowledge for all but the largest African languages - it is simply not possible in most contact situations to identify lexical and structural interferences because no linguistic information on one or several of the contact languages is available. The discussion of the word for 'panther' in Joola Bandial and its contact language Baïnounk Gubaher (Cobbinah, this volume pace Sagna (2008)) illustrates how a languageinternal analysis can become less plausible as soon as linguistic information on the contact language(s) is taken into account, while at the same time confirming the urgency of more basic descriptive and documentary research on West African languages.

2. The traditional setup for the 'ordinary fieldworking linguist' can be roughly summarised as 'one person, one language' - the classic 'lone wolf' scenario. This setup entails very limited manpower and a narrow disciplinary perspective, so that variation in descriptive grammars and dictionaries appears in general greatly reduced. A seemingly homogenous snapshot of a 'language' is taken, in past studies often even without mentioning where and with whom the data used were collected. Therefore, the existing linguistic material is incompatible with detailed sociolinguistic studies of variation - which, as demonstrated for instance by the study on social networks as a factor of language change conducted by Beyer (this volume), requires amounts of quantitative data way beyond the possibilities of basic descriptive and documentary efforts.

3. The perspectives of sociolinguists, anthropologists and descriptive and documentary linguists on notions like 'language', 'dialect', 'mother tongue', 'speech community', 'ethnicity', 'identity' and other contentious concepts have been, until recently, very incompatible in terms of acknowledging and parameterising variation and inventorying and comparing multilingual settings. Linguists are quite attached to models that make use of discrete notions like 'language' and associated concepts, although they may be hard to corroborate in practice and require a good understanding of extralinguistic factors and patterns and hierarchies of multilingualism. Linguists tend to take an axiomatic approach to many of these notions, since for them, the structural properties of a code (unconsciously or consciously idealised and homogenised) are their core concerns. Sociolinguists and anthropologists, in contrast, are notorious for deconstructing such terms to the extent that few, if any, generalisations can be made beyond the profile of an individual. Lüpke (this volume) addresses the contentious issue of identifying codes and retraces the laborious first steps of identifying speech communities, their language(s) and the relevance of linguistic repertoires for their identity.

\section{The contributions of this issue to West African contact linguistics}

The papers in this special issue constitute a first step in redressing this situation: they present the state of the art in approaches, analyses, and outlooks on the multifaceted topic they investigate, and make specific recommendations for avenues of research to pursue.

The first two articles chart the territory for the entire special issue by making the central but often neglected point that language contact is always a result of multilingual speakers being in contact with each other, and that to look at only the linguistic or only the social side of the process will never reveal the full picture. Tucker Child's contribution, a large-scale 
study on Mande and Atlantic languages in contact, sets the scene for linguistic approaches to the issue of multilingualism and language contact as a whole. Childs' contribution, though from a linguist's perspective, reminds us of the overarching issue that binds together the different disciplinary perspectives - that language contact and multilingualism are an outcome of people being in peaceful or conflictual contact. The scenario he develops is a sad one for Atlantic languages, which are, at the macro level, under pressure from Mande languages (Wolof, Fula and Temne exempted) because of the greater military success of the stratified Mande societies. At the same time, Childs stresses the need for integrated research on sociohistorical circumstances in addition to linguistic studies of languages in the area, notably research on the many virtually unknown small Atlantic languages. He calls researchers to collect ethnographic, historical, archaeological and geographic information-a new, holistic research paradigm that would allow us to understand present and past language contact, a topic he considers as important as it is, unfortunately, under-researched.

Caroline Juillard, in describing contact between speakers and languages in the Senegalese city of Ziguinchor, covers the sociolinguistic end of the spectrum. She offers a detailed account of the patterns of multilingualism attested in Ziguinchor. Multilingualism is so pervasive there that she even raises the question of being a multilingual as being a more salient marker of identity than the adherence to an ethnolinguistic group. She also stresses the creative, playful aspects of using different languages and strongly pleads for more research into this domain of multilingual exchanges, while at the same time highlighting the need for developing adequate theoretical frameworks for these complex situations. These, she argues, can only stem from interdisciplinary research involving local team members alongside researchers from outside in order to avoid both local ethnolinguistic stereotypes and Eurocentric constructions.

In their contributions, Abdourrahmane Diallo and Valentin Vydrin and Valentina Vydrina zoom in to the question of the structural outcomes of language contact at the micro level. Both articles investigate language contact involving Pular, the Guinean variety of the Atlantic language Fula. Diallo's article, however, focuses on Fula as the recipient language in an investigation of the impact of loanwords from different Mande languages in restructuring the Fula noun class system. Vydrin and Vydrina, on the other hand, focus on the Mande language Kakabe and identify contact-induced matter and pattern borrowings from Pular in it. Both articles communicate directly with Childs' contribution in that they demonstrate the need for small-scale studies that allow the linking of global trends to more localised and temporally limited scenarios, which may actually change direction over time. As such, the two articles strengthen Childs' central point that only more holistic approaches, drawing both on the interpretation of linguistic data and on a whole range of extralinguistic information, allow a satisfactory account of West African multilingualism. This is most noteworthy in Diallo's discussion of the difficulties of identifying the donor language of many of the Mande loanwords in Pular - only detailed knowledge of the history of contact and migration can offer conclusive evidence on this matter. At the same time, the articles demonstrate the importance of a basic linguistic description of all the different codes involved in a contact situation-however discrete or hybrid the actual spoken variety may turn out to be-as a necessary first step prior to describing language contact and analysing it as borrowing, codeswitching, mixed or hybrid language use, etc.

The issue of small-scale studies, new methodologies and the development of predictive models for contact-induced language change is one that also connects the next two contributions: Klaudia Dombrowsky-Hahn explicitly puts methodology at the very core of her study by testing and confirming Kaufman's (1988) prediction that the direction and intensity of borrowing depend on social patterns of contact. She does so by comparing genitive constructions and their functions in two varieties of the Senufo language Minyanka, of the Gur group of Niger-Congo, which are characterised by different contact situations-one variety being not in contact with the Mande language Bambara, the other exhibiting much 
contact with this vehicular language. Her article illustrates how crucial historical knowledge is in selecting different contact situations for research and in interpreting the data. Dombrowsky-Hahn argues strongly for the need not only to focus on the target language and a contact language, but also to take data from closely related languages into account when deciding whether a lexical or grammatical phenomenon is an instance of language contact or not. Further, she suggests a systematic comparison of linguistic subsystems that exhibit variation across language areas and, if possible, the collection and analysis of data on variation according to sociocultural groups as a further step forward.

The article by Klaus Beyer on social networks as a factor in language change constitutes a first instance of the social network model being applied in an African context. The application of this model captures change in progress, as it records data on micro-variation, showing how linguistic change spreads in a community by recording individual variation regarding labialisation and linking this to information on the social networks in which the individual participates and the position (s)he occupies in them.

Both Dombrowsky-Hahn's and Beyer's contributions compellingly demonstrate how hypotheses on linguistic change and the role of multilingualism and language contact in it can be tested by linking linguistic and sociocultural information and by studying patterns of actual language use.

The following two articles explicitly engage in a dialogue, since the authors collaborate in a research project on the Baïnounk languages of Senegal. The articles by myself and by Alexander Cobbinah are intended to complement each other in elucidating different aspects of language contact and multilingualism in this group of closely related languages.

My contribution describes the attempts of a descriptive linguist to come to terms with the complex issues surrounding the different aspects of identity in a Baïnounk community with a highly multilingual setting prior to conducting linguistic research. The article investigates multilingual profiles of speakers, domains associated with different languages of the multilingual repertoire, and attitudes associated with the different languages in connection with historical, ethnic, linguistic and political aspects of Baïnounk identity. This endeavour is deemed a necessary preliminary to identifying the object of a descriptive and documentary linguistic study in the absence of clear boundaries singling out discrete entities ready to be labelled 'language', 'dialect', 'ideolect', etc., and in the light of intense convergence patterns likewise impossible to analyse as code-switching, lexical or grammatical borrowing, shared retention or innovation.

Alexander Cobbinah, working in a another Baïnounk community with very similar patterns of multilingualism, explores the extensive lexical and structural contact points between Baïnounk and surrounding languages, while at the same time reflecting on the difficulty of assigning clear directionalities to interference processes in areas of intense language contact without written records. The findings from Baïnounk and surrounding languages show that an isolated analysis of any language spoken in this hotspot of linguistic diversity must remain incomplete, and that a perspective that takes language contact into account is absolutely crucial for adequate linguistic description. Cobbinah also stresses the difficulty and even absurdity of applying concepts like 'mother tongue' and 'ethnic identity' in the usual essentialist way in settings like the one encountered in Casamance, and draws our attention to the fact that the predominant scenarios of language death and endangerment do not hold here.

All the contributions introduced so far are concerned with language contact and multilingualism within the oral sphere. No account of language contact can be complete without taking into account language contact in and between the written and spoken modality. The final three contributions to the special issue do exactly this. Marie-Ève Humery investigates two different writing traditions among the Fula in the Futa Tooro of Senegal. Kristin Vold Lexander looks at patterns of multilingual language use in text messaging in 
Dakar, Senegal. Finally, Ingse Skattum reminds us of an important issue too often unconnected to linguistic and sociolinguistic research: the use of national languages in the Malian education system, against the backdrop of multilingualism and complex nested diglossic relationships between official, vehicular and minority languagesIn her article, Humery presents research on plurigraphic writing of the Pular in the Fuuta Tooro of Senegal, and discusses the choice of a Latin-based versus Arabic-based script for the writing of this Atlantic language in the context of identity in a contact situation with different writing system choices. Africa is often viewed as an oral continent, at least prior to the colonial period (see Olson and Torrance, 2001). In reality, the area in question is not only multilingual, but also multigraphic, since it features one of the often overlooked pre-colonial African writing traditions, so-called Ajami writing (the writing of languages other than Arabic in Arabic scripts), alongside the more recent writing of Pular in Latin characters. Her study shows that, just as oral language choice and preferences are governed by a variety of social, historical, religious and identity factors as well as by the situational settings, so is the choice of a written language and of a script. Once the proponents of Ajami writing, writers of Pular started to favour romanized Pular, mainly in order to differentiate themselves from the widespread and dominant Ajami writing tradition for Wolof (Wolofal). Humery's article also shows that not all the languages in an individual's repertoire occupy the same rank in spoken and written contexts.

This observation leads directly into Vold Lexander's study of well-wishing mobile phone text messages sent between students in Dakar. It appears that new technologies have a great power of attraction and offer creative new written roles to African national languages until recently confined to the oral sphere or informal adult literacy campaigns. At the same time, it emerges that not all national languages have the same place in this new technologically mediated multilingualism; rather, those languages with a vehicular status, Wolof and, to a lesser extent, Pular, win out over the other languages in the students' repertoires.

Skattum's expert description of national language education in Mali rounds off this topic by reminding us of all the ideologies associated with reading and writing. Mali has been one of the African countries pioneering the introduction of national languages into the formal education sector, investing in 11 of its national languages alongside the official language, French. The failure of bilingual education, Skattum succinctly argues, is due to a mismatch between the politically defined cultural, linguistic, and social objectives of bilingual education, the teaching models chosen, and the resources invested in reality to achieve the objectives. These contradictions are ultimately motivated by linguistic ideologies and attitudes towards languages that reflecting these ideologies: while, rhetorically, the goal of bilingual education is to valorise national languages and achieve a functional bilingualism in a national language and the official language French through the teaching of both languages at school, in reality parents, teachers and education planners alike see mastery of French in reading and writing as the primary goal, whether this is achieved through transition from a national language (which then merely serves to create the cognitive prerequisites for the successful learning of French) or through monolingual education from the outset. Skattum's contribution also testifies to the enormous irony present in the existence of a successful multilingual society outside the classroom and the failure to even partly recreate multilingualism at school, a topic that very often does not receive a fraction of the attention it deserves.

\section{Outlook}

The articles in this collection span a wide range of topics, and their broad orientation is reflected in the tremendous importance of collaborative interdisciplinary research. Even for single-handed studies the centrality of a multidisciplinary outlook is stressed by all the authors. The following focal points, around which such multi- and interdisciplinary work could be centred, emerge: 


\subsection{The centrality of language contact and multilingualism for language description and documentation}

Now is an ideal time to make connections between language contact and multilingualism as fields of investigation, and in particular to extend the link to language description and documentation. Language documentation is an emerging field of linguistics whose agenda, methods, and scope are being defined at the moment, because the new possibilities for creating large and publicly accessible electronic corpora of primary language data open up new possibilities for their content and potential uses. Funding opportunities for the documentation of endangered languages converge to permit collaborative documentary projects on a scale that allows the traditional agenda of (mainly single-handed) linguistic research on a language to be broadened. Documentation projects coupled with and providing data for studies on the effects of language contact are thus a crucial avenue of research to pursue. Such data have the potential to dramatically advance the linguistic analysis of the languages of the people groups involved. More empirical research on the individual languages and on their contact situation is urgently required while the languages in question, a considerable number of which are endangered, are still spoken in functioning speech communities.

\subsection{The importance of data on contact situations for sociolinguistics and multilingualism studies}

Sociolinguistic data from compatible theoretical backgrounds on different multilingual situations - involving one and the same language in contact with different languages, in rural vs. urban situations, different languages in similar multilingual settings etc.-will allow a better categorization and classification of these situations and will contribute to the development of testable models predicting structural outcomes of language contact based on social variables. Beyond their regional scope, studies addressing these issues will be of central relevance to different areas of linguistics - historical linguistics and typology, contact linguistics, sociolinguistics, anthropological linguistics, oral history, language endangerment research, multilingualism research and descriptive linguistics.

\subsection{The potential of an understanding of patterns of multilingualism for applied linguistics and education planning}

Records of multilingual language use in a given speech community will also be highly beneficial to efforts to implement languages into education and media, by informing the choice of language(s) to be used and because language materials can then reflect actual spoken and written language use. As such, they are of central importance to the fields of applied linguistics and education planning, since they will have the potential to challenge dominant theories of multilingualism and language endangerment, which almost exclusively focus on diglossic relationships between languages (Duchêne and Heller 2007; McLaughlin 2008), and models of language shift in which languages are given up rather than added. As a consequence, language planning and pedagogy efforts either have recourse to methods developed for monolingual communities where one language serves all communicative functions, or are based on assumptions about hierarchical relationships between the multiple languages of a speech community that may not be appropriate for the specific contact situation. New technologies are reshaping the functions and potentials for African languages as we speak. If globalization, language choice, character encoding issues etc. in this dynamic domain are to take the findings of multilingualism research into account, researchers need to engage in a dialogue with software developers and companies now. 


\section{Conclusion}

It is hoped that this issue will serve to fuel more research in the near future that will make West African multilingualism better studied and better known to scholars, education planners and the general public. The persistence of multilingualism and the linguistic creativity manifest in the playful use of different languages in every day interactions in Africa as a whole remains strikingly under-researched and under-publicized, especially against the backdrop of language death and expanding monolingualism elsewhere in the world. The effortless mastery of several languages is disturbing, however, for those who take essentialist perspectives and see it as a problem rather than a resource, and for the dominant, conflictual model of multilingualism. These models reflect strong Eurocentric ideologies, but are widespread and are adopted by most government agencies and NGOs, many Western linguists working on these languages and even by the communities themselves. Through this first attempt at charting the ground for a better understanding of West African multilingualism and its social functions, we hope to be able not only to draw attention to its artful aspects in expressing, manipulating, and changing aspects of identity, but also to make this 'African success story' better known and to explore the potential of this rich pool of diversity.

\section{References}

Ajayi, J.F. Ade and Crowder, Michael. 1985. History of West Africa. Vol. 1. Harlow: Longman.

Amselle, Jean-Loup. 1990. Logiques métisses. Anthropologie de l'identité en Afrique et ailleurs. Paris: Payot.

Amselle, Jean-Loup. 1996. L'étranger dans le monde manding et en Grèce ancienne; quelques points de comparaison. Cahiers d'Études Africaines 144:755-761.

Amselle, Jean-Loup and Royal, Claudia. 1998. Mestizo logics: anthropology of identity in Africa and elsewhere. Mestizo spaces. Stanford, California: Stanford University Press.

Amselle, Jean-Loup and M'Bokolo, Elikia. 1999. Au coeur de l'ethnie : ethnies, tribalisme et Etat en Afrique. Sciences humaines et sociales. Paris : La Découverte.

Beyer, Klaus. 2006. Das Pana im Netzwerk arealer Beziehungen: Das Lexikon. In: Kerstin Winkelmann and Dymitr Ibriszimov (eds.). Zwischen Bantu und Burkina. Festschrift für Gudrun Miehe zum 65. Geburtstag. Köln: Köppe, 9-22.

Beyer, Klaus. 2009. Double negation marking: a case of contact-induced grammaticalization in West Africa?. In: Norbert Cyffer, Erwin Ebermann and Georg Ziegelmeyer. (eds.). Negation patterns in West Africa and beyond. Amsterdam: John Benjamins, 205-222.

Brooks, George E. 1980. Kola trade and state-building : Upper Guinea Coast and Senegambia, $15^{\text {th }}-17^{\text {th }}$ centuries. Brookline, Massachusetts: African Studies Center Boston University.

Brooks, George E. 1993. Landlords and strangers : ecology, society and trade in Western Africa, 1000-1630. Boulder, Colorado - Oxford: Westview.

Bruijn, Mirjam de and Dijk, Hans van (éds.). 1997. Peuls et Mandingues : dialectiques des constructions identitaires. Hommes et sociétés. Leyde - Paris : Afrika-Studiecentrum - Karthala.

Canut, Cécile 1996. Dynamiques linguistiques au Mali. Paris : Didier Éruditions.

Davidson, Basil. 1998. West Africa before the colonial era. A history to 1850. London - New York: Longman.

Dimmendaal, Gerrit. 2008. Language ecology and linguistic diversity on the African continent. Language and Linguistics Compass 2:840-858.

Dombrowsky-Hahn, Klaudia. 1999. Phénomènes de contact entre les langues minyanka et bambara (sud du Mali). Köln : Köppe. 
Dreyfus, Martine and Juillard, Caroline 2007. Le plurilinguisme au Sénégal. Langues et identités en devenir. Paris : Karthala.

Drolc, Ursula. 2005. Die Cangin-Sprachen. Vergleichende Grammatik und Rekonstruktion. Universität zu Köln.

Duchêne, Alexandre and Heller, Monica. 2007. Discourses of endangerment: sociolinguistics, globalization and social order. In: Alexandre Duchêne and Monica Heller. (eds.). Discourses of endangerment. Interest and ideology in the defense of languages. London - New York: Continuum.

Dumestre, Gérard. 1994. La dynamique des langues au Mali : le trinôme langues régionales bambara - français. In : Gérard Dumestre. (éd.). Stratégies communicatives au Mali : langues régionales, bambara, francais. Paris: Didier Érudition, 3-11.

Güldemann, Tom. 2008. The Macro-Sudan belt: towards identifying a linguistic area in northern sub-Saharan Africa. In: Bernd Heine and Derek Nurse. (eds.). A linguistic geography of Africa. Cambridge: Cambridge University Press, 151-185.

Haust, Delia. 1995. Codeswitching in Gambia: eine soziolinguistische Untersuchung von Mandinka, Wolof und Englisch in Kontakt. Köln: Köppe.

Heine, Bernd and Kuteva, Tania. 2005. Language contact and grammatical change. Cambridge: Cambridge University Press.

Heine, Bernd and Nurse, Derek (eds.). 2008. A linguistic geography of Africa. Cambridge: Cambridge University Press.

Juillard, Caroline. 1995. Sociolinguistique urbaine. La vie des langues à Ziguinchor (Sénégal). Paris : Presses du Centre National de la Recherche Scientifique (CNRS).

Kastenholz, Raimund. 1996. Sprachgeschichte im West-Mande. Vol. 2: Mande languages and linguistics. Köln: Köppe.

Levtzion, Nehemia. 1973. Ancient Ghana and Mali. London: Methuen.

Matras, Yaron, McMahon, April and Vincent, Nigel (eds.). 2006. Linguistic areas. Convergence in historical and typological perspective. Houndmills: Palgrave Macmillan.

Matras, Yaron. 2009. Language contact. Cambridge: Cambridge University Press.

McLaughlin, Fiona. 2001. Dakar Wolof and the configuration of an urban identity. Journal of African Cultural Studies 14:153-172.

McLaughlin, Fiona. 2008. The ascent of Wolof as an urban vernacular and national lingua franca in Senegal. In: Cécile Vigouroux and Salikoko S Mufwene. (eds.). Globalization and language vitality: Perspectives from Africa, London: Continuum, 142-170.

Mous, Maarten. 2003. The making of a mixed language: the case of Ma'a/Mbugu. Amsterdam - Philadelphia: John Benjamins.

Myers-Scotton, Carol. 1993. Social motivations for codeswitching: evidence from Africa. Oxford: Oxford University Press.

Myers-Scotton, Carol. 2002. Contact linguistics: Bilingual encounters and grammatical outcomes. Oxford: Oxford University Press.

Nicolaï, Robert. 2005. Language processes, theory and description of language change, and building on the past: lessons from Songhay. In: Zygmunt Frajzyngier, Adam Hodges and David S. Rood. (eds.). Linguistic diversity and language theories, Amsterdam Philadelphia: John Benjamins, 81-104.

Olson, David R. and Torrance, Nancy. 2001. Conceptualizing literacy as a personal skill and as a social practice. In: David R. Olson and Nancy Torrance. (eds.). The making of literate societies, Malden, Massachusetts - Oxford: Blackwell, 3-18.

Podzniakov, Konstantin. 2007. Études atlantiques comparatives : questions de méthodologie. Paris: Mémoires de la Societé de Linguistique de Paris.

Romaine, Suzanne. 1989. Bilingualism. Oxford: Blackwell. 
Sapir, J. David. 1971. West Atlantic. In: Thomas A. Sebeok. (ed.). Current trends in linguistics, vol. 7: Linguistics in Sub-Saharan Africa, The Hague - Paris: Mouton, 45112.

Schreiber, Henning. 2008. Eine historische Phonologie der Niger-Volta-Sprachen. Köln: Köppe.

Swigart, Leigh. 1994. Cultural Creolisation and Language Use in Post-Colonial Africa: The Case of Senegal. Africa: Journal of the International African Institute 64:175-189.

Tamari, Tal. 1991. The development of caste systems in West Africa. Journal of African History 32:221-250.

Tamari, Tal. 1997. Les castes de l'Afrique occidentale : artisans et musiciens endogames. Nanterre: Société d'ethnologie.

Thomason, Sarah Grey and Kaufman, Terrence. 1988. Language contact, creolization, and genetic linguistics. Berkeley: University of California Press.

Thomason, Sarah Grey. 2001. Language contact. Washington, D.C. : Georgetown University Press.

Turay, Abdul Karim 1978. Language contact: Mende and Temne - a case study. Africana Marburgensia 11:55-73.

Vigouroux, Cécile and Mufwene, Salikoko S. (eds.). 2009. Globalization and language vitality: perspectives from Africa. London: Continuum.

Vydrin, Valentin F. 1989. Reflection of the nominal classification in Manden and SouthWestern Mande languages: the connection category. Zeitschrift für Phonetik, Sprachwissenschaft und Kommunikationsforschung 42:90-101.

Weinreich, Uriel. 1953. Languages in contact. London - Paris - The Hague: Mouton.

Williamson, Kay and Blench, Roger. 2000. Niger-Congo. In: Bernd Heine and Derek Nurse. (eds.). African languages. An Introduction. Cambridge: Cambridge University Press, 11-42.

Wilson, William André Auquier. 1989. Atlantic. In: John Bendor-Samuel. (ed.). The NigerCongo languages, New York - London: Lanham, 81-104. 
Journal of language contact - THEMA 3 (2010)

www. jlc-journal.org 